\title{
Mollusks of the Rocky Intertidal Zone at Three Sites in Oaxaca, Mexico
}

\author{
Pedro Flores-Rodríguez ${ }^{1}$, Rafael Flores-Garzaํㅜ, Sergio García-Ibáñez ${ }^{1}$, \\ Carmina Torreblanca-Ramírez ${ }^{2}$, Lizeth Galeana-Rebolledo ${ }^{1}$, Enedina Santiago-Cortes ${ }^{1}$ \\ ${ }^{1}$ Laboratorio de Ecología Costera y Sustentabilidad, Unidad Académica de Ecología Marina, Universidad \\ Autónoma de Guerrero, Acapulco, Mexico \\ ${ }^{2}$ Doctorado en Ciencias Ambientales, Unidad de Ciencias de Desarrollo Regional, Universidad Autónoma de \\ Guerrero, Acapulco, Mexico \\ Email: pfloresrodriguez@yahoo.com, rfloresgarza@yahoo.com
}

Received 15 August 2014; revised 20 September 2014; accepted 2 October 2014

Copyright (C) 2014 by authors and Scientific Research Publishing Inc.

This work is licensed under the Creative Commons Attribution International License (CC BY).

http://creativecommons.org/licenses/by/4.0/

(c) (i) Open Access

\section{Abstract}

The community of mollusks at three rocky intertidal zone in Oaxaca, Mexico was analyzed. Two samplings per site were conducted. At each sampling the inspected area was $10 \mathrm{~m}^{2}$. The sampling unit was $1 \mathrm{~m}^{2} .5862$ specimens were examined. 68 mollusks species were identified. The families better represented in species richness were: FISSURELLIDAE, MURICIDAE, LOTIIDAE, MYTILIDAE, CHAMIDAE, ISCHNOCHITONIDAE y CHITONIDAE. The species that had the greatest density were Lottia discors, Siphonaria palmata, Lottia acutapex, Chormoytilus palliopunctatus, Brachidontes adamsianus, Chton articulatus e Ischnochiton muscarius. The species with the widest distribution represent $11.76 \%$. With irregular distribution was found in $58.82 \%$ of the species. The gastropod Crucibulummonticulus, the bivalve $C$. palliopunctatus and the polyplacophoran $C$. articulatus had the greatest size. The value of diversity index was $\mathrm{H}^{\prime}=4.29$ bits/ind. and $\mathrm{J}^{\prime}=0.72$. The mollusks community in the rocky intertidal zone study sites is characterized by small size, because they rarely exceed seventy millimeters. The values of $\mathrm{H}^{\prime}$ and $\mathrm{J}^{\prime}$ indicate that the mollusk community in the study area has a high diversity and high uniformity, corresponding to mature and stable communities in a tropical region.

\section{Keywords}

Intertidal Zone, Oaxaca, Biodiversity, Mollusks 


\section{Introduction}

The Commission for Environmental Cooperation of North America determined the existence of 24 marine ecoregions. Seven ecoregions are located in Mexico. The Mexican Pacific Transitional (MPT) forms part of these seven regions and is composed of the states of Jalisco, Colima, Michoacán, Guerrero and Oaxaca and the southern tip of Baja California Sur. It is characterized as a region of high productivity, as a result of warmer ocean temperatures; tropical marine fauna is very different to that found in areas influenced by the Humboldt and California currents.

The coasts of MPT are comprised of cliffs and have rocky and sandy bottoms. These sites are suitable for development of biotic communities. Mollusks are part of these communities and this group has pointed out that knowledge is scarce and we have a great ignorance of the status these organisms in the intertidal zone of the MPT [1].

For the State of Oaxaca the National Commission for the Knowledge and Use of Biodiversity (Comision Nacional Para el Uso y Conocimiento de la Biodiversidad; CONABIO) stated that there are five marine priority areas for the conservation of coastal and ocean biodiversity; about these regions CONABIO has highlighted the lack of knowledge about the diversity of marine species [2], hence it is necessary to conduct research to gain information on the species diversity and in addition to analyze the ecological aspects of populations and communities.

There are reports of mollusks for different MPT sites that deal with biodiversity [3]-[9] and ecological parameters, among which species richness, density, diversity index, dominance and sizes were considered [10]-[24]. Other reports provide information on the biology and ecology of mollusks and commercial use [25] [26], mollusks coral area [27] [28] and continental shelf [29] [30]. Mollusk zonation reports were also found [12] [31] [32].

The lack of knowledge about mollusks in many places of the MPT, was the principal motivation for carrying out this research and focusing on the GASTROPODA, BIVALVIA and POLYPLACOPHORA Classes and objectives were: 1) to determine species richness; 2) to analyze the composition of the community based on the most represented families; 3 ) to estimate the density; 4) to determine the distribution of the species in the study area; 5) to analyze the size composition of populations; and 6) to estimate the diversity index.

\section{Methodology}

\subsection{Study Area}

In Oaxaca the weather is subhumid tropical, with summer rains [33]. The coastline has an approximate length of $568 \mathrm{~km}$, is part of the Pacific coast's to collision zone, which is characterized by high reliefs of rocks and hills with rocky cliffs. Primary coasts are formed by diastrophic processes. Secondary coasts retain their shape through erosion, waves and marine deposition [34].

The rocks of the hydrological basins that drain into the sea are diverse in age and lithology [35]. In the study area, the lowest tide levels occur in winter and the highest levels occur in the summer. Tides are mixed, with large diurnal inequality, the average range is $1.4 \mathrm{~m}$ [36].

Three sites were sampled, which are located in priority marine regions 34 and 35, each location was geographically referenced and described according to the following criteria: type of substrate, type of rock, substrate stability and wave exposure. The sampling sites were described based on the report [37], geological maps of the National Institute of Statistics, Geography and Informatics [38] [39] and field observations (Table 1).

These sites vary in type, substrate stability and wave exposure. Substrate types were classified as: a) Massif rocks: fixed structures such as walls, cliffs, terraces, etc.; b) Blocks: loose rock larger than $50 \mathrm{~cm}$ in diameter, made of rocks submerged and immovable or that are difficult to move about by the impact of waves; c) Boulders: loose rock of size less than 50 and greater than $8 \mathrm{~cm}$ in diameter, rocks that can be easily moved by the impact of waves; d) Gravel: loose rock no more than $8 \mathrm{~cm}$ in diameter. The stability of the substrate was classified as: a) High: when the substrate remains virtually unchanged by the impact of waves; b) Middle: when the impact of the waves does not change the configuration of the substrate but there is rock movement; c) Low: when the site configuration changes due to the impact of waves, most of the rocks are moved. The wave exposure was classified as: a) High: when the wave hits the substrate in a free manner, usually the sites that have this type of waves are outside of the protection of any barriers such as bays or hooks; b) Middle: when the impact of the wave on 
Table 1. Sampling sites considered in the study, indicating the location and relevant characteristics of the habitat.

\begin{tabular}{|c|c|c|c|c|c|c|c|}
\hline \multirow{2}{*}{ Site } & \multicolumn{2}{|c|}{ Coordinates } & \multirow{2}{*}{$\begin{array}{l}\text { Length } \\
\text { of thesite }\end{array}$} & \multirow{2}{*}{$\begin{array}{l}\text { Type of } \\
\text { substrate }\end{array}$} & \multirow{2}{*}{$\begin{array}{l}\text { Type of } \\
\text { rock }\end{array}$} & \multirow{2}{*}{$\begin{array}{l}\text { Subtrate } \\
\text { stability }\end{array}$} & \multirow{2}{*}{$\begin{array}{l}\text { Wave } \\
\text { exposure }\end{array}$} \\
\hline & Latitud N & Longitud W & & & & & \\
\hline Carrizalillo & $15^{\circ} 51 ' 35.19^{\prime \prime}$ & $97^{\circ} 04^{\prime} 45.57^{\prime \prime}$ & 208 meters & $\begin{array}{c}\text { Massifs and blocks. } \\
\text { Very roufh and abundant } \\
\text { hollows } \\
\text { Among the blocks are boulders } \\
\text { and gravel on sand }\end{array}$ & $\begin{array}{l}\text { Sedimentary rocks conglomerate Q (cg), } \\
\text { formed in the Cenozoic } \\
\text { and Quaternary [38] }\end{array}$ & Middle & Middle \\
\hline Coral & $15^{\circ} 51^{\prime} 47.50^{\prime \prime}$ & $97^{\circ} 05^{\prime} 14.34^{\prime \prime}$ & 147 meters $^{7}$ & $\begin{array}{l}\text { Massifs rocks alternating with } \\
\text { sandy areas } \\
\text { The rocks massifs are large areas } \\
\text { of smooth } \\
\text { Surfaces, alternating with } \\
\text { crevices and hollows }\end{array}$ & $\begin{array}{l}\text { Sedimentary rocks conglomerate Q (cg), } \\
\text { formed in the Cenozoic } \\
\text { and Quaternary [38] }\end{array}$ & High & Middle \\
\hline Punta Cometa & $15^{\circ} 51^{\prime} 47.50^{\prime \prime}$ & $97^{\circ} 05^{\prime} 14.34^{\prime \prime}$ & 73 meters & $\begin{array}{l}\text { Rocks massifs with large areas of } \\
\text { smooth } \\
\text { Surfaces and few grooves or } \\
\text { channels }\end{array}$ & $\begin{array}{l}\text { Metamorphic rock, type Gneiss J (Gn) } \\
\text { of Mesozoic and Jurassic period [39] }\end{array}$ & High & High \\
\hline
\end{tabular}

the substrate is hindered by barriers or smoothing, as can occur at sites that are in front of the entrance of bays or at a distance from a wall of hooks, it also happens in places where subtidal rocky substrate merges or is shallow and reduces the direct impact of the waves to the substrate; c) Low: when the wave does not directly hit the substrate, since the sites are protected by different types of barriers [18].

\subsection{Field Methodology}

Two samples were conducted in Carrizalillo and Coral and one in Punta Cometa between February and November 2011. Sampling was performed during the hours of low tide at new moon days.

To carry on the quantification of organisms an area of $10 \mathrm{~m}^{2}$ was sampled per site. Sampling was systematic [40].

The starting point was randomly selected and then a nylon rope $30 \mathrm{~m}$ long was placed parallel to the shore on the intertidal zone using a PVC pipe square frame $1 \mathrm{~m}$ per side to delimit the sampling unit. Once the starting point was established, the PVC frame was placed at the selected point. All mollusks that were found alive in the quadrants were collected and placed into a plastic container filled with seawater and protected from exposure to direct sunlight. After completing the collection, a $2 \mathrm{~m}$ intersection along the rope was measured then the frame was again repositioned to define the following sampling unit. This procedure was repeated ten times along the nylon rope. Upon sample completion, the specimens' preservation consisted of placing them in labeled jars containing $96 \%$ ethyl alcohol. They were then taken to the laboratory to be identified, quantified and measured.

To complement the inventory of species searches were conducted to locate species that were not found within the quadrants in the quantitative samples.

The taxonomic identification required a confirmation stage in the laboratory. For the identification the characteristics of the shell, the soft body parts and specialized literature [41]-[44] were used. Nomenclature GASTROPODA and BIVALVIA Class updated according to the criteria of [45] [46]. OPISTHOBRANCHIA Subclass according to [47] and the POLYPLACOPHORA Class updated according to [48]. After the identification and measurement of specimens, they were deposited in the Malacological Collection of the Unidad Académica de Ecología Marina, Universidad Autónoma de Guerrero.

\subsection{Data Analysis}

Richness represents a based on the number of species found in the samples. The community composition was analyzed using the representation of families, which was evaluated based on species richness and abundance of 
organisms per Family. Density was measured by estimating the average number of specimens $/ \mathrm{m}^{2}$.

To classify the species distribution, the following criteria were used: a) wide, the species was present at all three sites; b) regular, it was present in two; c) irregular, it was present at one.

The analysis of structure of populations was considered by measuring the length, and obtained the statistical descriptive values such as maximum, minimum, mean and standard deviation expressed in millimeters was obtained using a digital vernier type caliper (accuracy $0.01 \mathrm{~mm}$ ). The diversity was measured using the Shannon-Weaver (H') index and the evenness index of Pielou (J') or equity [49].

\section{Results}

5862 specimens were examined. 68 mollusks species were identified: 49 species of GASTROPODA Class, eight BIVALVIA and 11 POLYPLACO2

Table 2. Families and species of the GASTROPODA Class, abundance at the site, density, distribution and descriptive statistics of length, at three sites in Oaxaca, Mexico.

\begin{tabular}{|c|c|c|c|c|c|c|c|c|c|}
\hline \multirow{2}{*}{ Families/Species } & \multicolumn{3}{|c|}{ N. } & \multirow{2}{*}{$\begin{array}{c}\text { De. } \\
\text { Org. } / \mathrm{m}^{2}\end{array}$} & \multirow{2}{*}{ D. } & \multicolumn{4}{|c|}{ Length(mm) } \\
\hline & 1 & 2 & 3 & & & Min. & Max. & Ave. & Sd. \\
\hline \multicolumn{10}{|c|}{ LOTTIIDAE Gray, 1840} \\
\hline Lottia mesoleuca (Menke, 1851) & 2 & 34 & 20 & 1.12 & $\mathrm{~W}$ & 4.52 & 23 & 10.09 & 3.79 \\
\hline Lottia mitella (Menke, 1847) & 20 & 43 & 213 & 5.52 & $\mathrm{~W}$ & 4.8 & 19.7 & 8.48 & 2.99 \\
\hline Lottia acutapex (Berry, 1960) & & 423 & & 8.46 & I & 3.48 & 17.1 & 9.98 & 2.32 \\
\hline Lottia discors (Philippi, 1849) & 480 & 26 & 168 & 13.48 & $\mathrm{~W}$ & 5.67 & 43.3 & 21.01 & 8.7 \\
\hline Lottia pediculus (Philippi, 1846) & 70 & 1 & & 1.42 & $\mathrm{R}$ & 5.76 & 21.2 & 12.13 & 3.51 \\
\hline Tectura fascicularis (Menke, 1851) & 10 & 7 & & 0.034 & $\mathrm{R}$ & 5.05 & 27.2 & 15.86 & 6.71 \\
\hline
\end{tabular}

FISSURELLIDAE Fleming, CA, 1822

Fissurella rubropicta Pilsbry, 1890

Fissurella (Cremides) microtrema Sowerby, 1835

Fissurella nigrocincta Carpenter, 1856

Fissurella gemmata Menke, 1847

Fissurella longifissa Sowerby, 1866

Fissurella morrisoni McLean, 1970

Fissurella spongiosa Carpenter, 1857

Fissurella asperella Sowerby, 1835

Fissurella obscura Sowerby, 1835

Tegula globulus (Carpenter, 1857)

Nerita scarbricosta Lamark, 1822

Nodilittorina aspera (Philippi, 1846)

Nodilittorina modesta (Philippi, 1846)

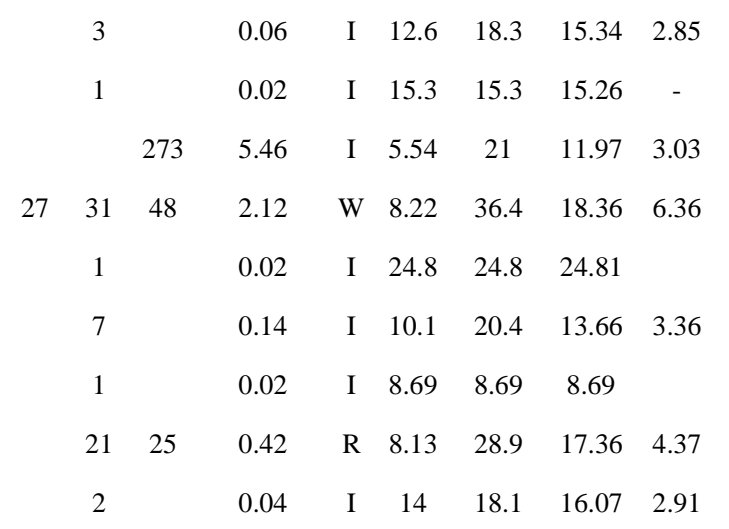

TROCHIDAE Rafinesque, 1815

35

$\begin{array}{llllll}0.7 & \text { I } & 4.14 & 29 & 9.08 & 3.91\end{array}$

NERITIDAE

3

$\begin{array}{llllll}0.06 & \text { I } & 8.51 & 12.3 & 10.12 & 1.96\end{array}$

LITTORINIDAE Children, 1834

$60 \quad 231$

322
$\begin{array}{llllll}5.82 & \mathrm{R} & 1.56 & 12.1 & 4.03 & 1.34\end{array}$
$\begin{array}{llllll}6.44 & \text { I } & 1.13 & 13.7 & 4.45 & 1.75\end{array}$

RISSOIDAE 


\section{Continued}

Rissoina stricta Menke, 1850

2

$\begin{array}{llllll}0.04 & \text { I } & 6.46 & 7.21 & 6.835 & 0.53\end{array}$

VERMETIDAE

Petaloconchus complicatus Dall, 1908

Serpulorbis margaritaceus (Chenu, 1844 ex Rousseau, MS)

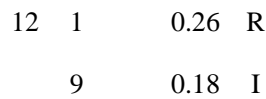

CERITHIDAE (Fleming, 1822)

Rhinoclavis (O.) gemmata (Hinds, 1844)

CALYPTRAEIDAE (Lamarck, 1809)

Crucibulum monticulus Berry, 1969

Crucibulumum brella (Deshayes, 1830)

Crucibulum subacuatum Berry, 1963

Crucibulum scutellatum (Wood, 1828)

MURICIDAE (Follows Vokes, 1996)

Mancinella speciosa (Valenciennes, 1832)

Mancinella triangularis (Blaindville, 1832)

Stramonita biseralis (Blanville, 1832)

Vasula melones (Duclos, 1832)

Acanthais brevidentanta (Wood, 1828)

Plicopurpura pansa (Gould, 1853)

Plicopurpura columellaris ( Lamarck, 1822)

Trachypollia lugubris (C. B. Adams, 1852)

10

$48 \quad 67$

$\begin{array}{llllllll}138 & 17 & 3.1 & \mathrm{R} & 4.94 & 17.8 & 10.61 & 2.2\end{array}$

$\begin{array}{llllllll}40 & 29 & 1.38 & \mathrm{R} & 3.91 & 31.4 & 12.86 & 5.02\end{array}$

$\begin{array}{llllllll}16 & 2 & 0.36 & \mathrm{R} & 21.2 & 46.6 & 38.89 & 8.2\end{array}$

$\begin{array}{lllllll}17 & 0.34 & \text { I } & 18.1 & 28.2 & 21.53 & 2.96\end{array}$

$\begin{array}{llllll}1 & 0.02 & \text { I } & 29.6 & 29.6 & 29.63\end{array}$

22

$\begin{array}{llllll}0.08 & \mathrm{R} & 11.4 & 23.3 & 18.26 & 5.75\end{array}$

FASCIOLARIIDAE (McLean, 1996)

Leucozonia cerata (Wood, 1828)

Opeatostoma pseudodon (Burrow, 1815)

Engina tabogaensis Bartsch, 1931

Cantharus sanguinolentus (Duclos, 1833)
2

BUCCINIDAE

\section{COLUMBELLIDAE (Swainson, 1840)}

Columbella fuscata Sowerby, 1832

Mitrella xenia (Dall, 1919)

Mitrella ocelata (Gmelin, 1791)

MITRIDAE (Swainsom, 1829)

Mitra tristis Broderip, 1836

6

CONIDAE (Fleming, 1822)

Conus nux Broderip, 1833

2

Conus fergusoni Sowerby, 1873
$84 \quad 1$

39

$73 \quad 3$ $\begin{array}{llllll}0.06 & \text { I } & 27.1 & 41.5 & 32.67 & 7.75\end{array}$

$\begin{array}{llllll}0.04 & \text { I } & 33.4 & 33.7 & 33.58 & 0.21\end{array}$

$\begin{array}{llllll}0.06 & \text { I } & 12.8 & 22.5 & 16.09 & 5.54\end{array}$

$\begin{array}{llllll}0.04 & \text { I } & 22.8 & 23.7 & 23.24 & 0.57\end{array}$

$\begin{array}{llllll}1.7 & \mathrm{R} & 8.32 & 21.2 & 14.07 & 3.26\end{array}$

$\begin{array}{llllll}0.78 & \text { I } & 1.89 & 13.6 & 6.18 & 2.19\end{array}$

$\begin{array}{llllll}0.04 & \mathrm{R} & 4.23 & 11.7 & 9.78 & 1.41\end{array}$

$\begin{array}{llllll}0.014 & \mathrm{R} & 9.82 & 14.3 & 12.31 & 1.61\end{array}$

$\begin{array}{llllll}0.04 & \text { I } & 17.6 & 23.8 & 20.66 & 4.36\end{array}$

$\begin{array}{llllll}1 & 0.02 & \text { I } & 25.1 & 25.1 & 25.14\end{array}$

ONCHIDIIDAE 


\section{Continued}

$\begin{array}{ccccccccccc}\text { Hoffmanola hansi Marcus \& Marcus, } 1967 & 16 & 14 & 1 & 0.62 & \text { W } & & & & & \\ & \text { SIPHONARIDAE (Gray, 1827) } & & & & & & & & \\ \text { Siphonaria gigas Sowerby, 1825 } & & 7 & & 0.14 & \text { I } & 10.5 & 16.9 & 13.82 & 2.69 \\ \text { Siphonaria maura Sowerby, 1835 } & 85 & 73 & 3.16 & \text { R } & 1.14 & 18.1 & 10.05 & 3.04 \\ \text { Siphonaria palmata Carpenter, 1857 } & 137 & 379 & 16 & 10.64 & \text { W } & 2.92 & 18.1 & 8.78 & 2.36\end{array}$

N.: Number of test organism per site; 1: Carrizalillo; 2: Coral; 3: Punta Cometa; De.: Density; D.: Distribution; W.: Wide; R.: Regular; I.: Irregular; Min.: Minimum; Max.: Maximum; Ave.: Average; and Sd.: Standard deviation.

Table 3. Families and species of the BIVALVIA and POLYPLACOFORA Classes, abundance at the site, density, distribution and descriptive statistics of length, at three sites in Oaxaca, Mexico.

Families/Species
Length (mm)

Min. Max. Ave. Sd.

\section{BIVALVIA}

MYTILIDAE (Rafinesque, 1815)

Brachidontes adamsianus (Dunker, 1857)

Brachidontes semilaevis (Menke, 1849)

Choromytilus palliopunctatus (Carpenter, 1857)

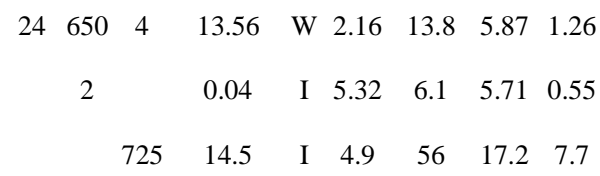

ISOGNOMONIDAE (Woodring, 1925 (1828))
92

$\begin{array}{llllll}1.84 & \text { I } & 5.6 & 30.9 & 15.7 & 5.4\end{array}$

OSTREIDAE (Rafinesque, 1815)

Crassostrea palmula (Carpenter, 1857)

Crassostrea prismatica (Gray, 1825)

CHAMIDAE (Lamarck, 1809)

Chama (chama) coraloides Revee, 1846

Chama mexicana Carpenter 1857

POLYPLACOPHORA

ISCHNOCHITONIDAE (Dall, 1889)

Ischnochiton (I.) muscarius (Reeve, 1847)

Stenoplax (S.) limaciformis (Sowerby \& Broderip 1832)

Stenoplax (S.) regulata (Sowerby, 1832))

CALLISTOPLACIDAE (Pilsbry, 1893)

Callistochiton elenensis (Sowerby, 1832)

Callistoplax retusa (Sowerby in Broderip \& Sowerby, 1832)
1084

3

1 $\begin{array}{llllll}1 & 0.02 & \text { I } & 24.4 & 24.4 & 24.4\end{array}$

$\begin{array}{llllll}1 & 0.02 & \text { I } & 48.9 & 48.9 & 48.9\end{array}$ $\begin{array}{llllllll}38 & 2 & 0.8 & \mathrm{R} & 5 & 38.1 & 16.3 & 8.05\end{array}$

\section{4}

1 $\begin{array}{llllll}2.24 & \text { R } & 3.71 & 21.1 & 11.5 & 3.73 \\ 0.06 & \text { I } & 8.53 & 29.9 & 16 & 6.3 \\ 0.02 & \text { I } & 5.33 & 5.33 & 5.33 & \end{array}$

CHAETOPLEURIDAE (Plate, 1899)

Chaetopleura (C.) hanselmani (Ferreira, 1982) 


\title{
Continued
}

CHITONIDAE (Rafinesque, 1815)

\author{
Chiton (C.) articulatus Sowerby, 1832 \\ Chiton (C.) albolineatus Broderip \& Sowerby, 1829 \\ Tonicia (T.) forbesii forbesii (Carpenter, 1857)
}

$\begin{array}{lllllllll}42 & 29 & 48 & 2.38 & \mathrm{~W} & 5.71 & 57.7 & 27.6 & 13.1 \\ 47 & 2 & & 0.98 & \mathrm{R} & 7.33 & 48.4 & 22.3 & 8.58 \\ 1 & & & 0.02 & \mathrm{I} & 13.1 & 13.1 & 13.1 & \end{array}$

TONICELLIDAE (Simroth, 1894)

Lepidochitona sp1

2

$\begin{array}{lllll}0.04 & \text { I } & 3.19 & 3.19 & 3.19\end{array}$

N.: Number of test organism per site; 1: Carrizalillo; 2: Coral; 3: Punta Cometa; De.: Density; D.: Distribution; W.: Wide; R.: Regular; I.: Irregular; Min.: Minimum; Max.: Maximum; Ave.: Average; and Sd.: standard deviation.

On tours conducted outside of the quadrants, they found four species of OPISTHOBRANCHIA Subclass: Berthelina chloris (Dall, 1918), Elysia sp1, Glossodoris sedna (Marcus y Marcus, 1967) and Mexichromis tura (Marcus y Marcus, 1967).

The GASTROPODA Class, showed the highest relative abundance (67.66\%), followed by BIVALVIA (27.31\%) and POLYPLACOPHORA (5.03\%).

26 Families were identified, of which 17 are of the GASTROPODA Class, four are from the BIVALVIA Class and five are of the POLYPLACOPHORA Class.

The Families of the GASTROPODA Class better represented in species richness were FISSURELLIDAE (nine species), MURICIDAE (eight species), LOTTIIDAE (six species) (Figure 1). The Family best represented in relative abundance was LOTTIDAE with $38.25 \%$, followed by SIPHONARIDAE with $17.57 \%$. In the BIVALVIA Class, the best represented families in species richness were MYTILIDAE (three species) and CHAMIDAE (two species).

The best represented in relative abundance was MYTILIDAE with $87.75 \%$. In the POLYPLACOPHORA Class, the best represented families in species richness were ISCHNOCHITONIDAE and CHITONIDAE with 3 species each. The best represented Family in relative abundance was CHITONIDAE with 57.28\%.

The estimated density was 117.84 organisms $/ \mathrm{m}^{2}$, which is divided into 79.32 gastropods $/ \mathrm{m}^{2}, 32.02$ bivalves $/ \mathrm{m}^{2}$ and 5.9 polyplacophorans $/ \mathrm{m}^{2}$.

The species of the GASTROPODA Class that showed the highest density were Lottia discors (Philippi, 1849) (13.48 organisms $\left./ \mathrm{m}^{2}\right)$, Siphonaria palmata Carpenter, $1857\left(10.64\right.$ organisms $\left./ \mathrm{m}^{2}\right)$, Lottia acutapex (Berry, 1960) $\left(8.46\right.$ organisms $\left./ \mathrm{m}^{2}\right)$, and Nodilittorina modesta (Philippi, 1846) $\left(6.44\right.$ organisms $\left./ \mathrm{m}^{2}\right)$. In BIVALVIA Class, species that showed the highest density were Chormoytilus pallopunctatus (Carpenter, 1857) (14.5 organisms $/ \mathrm{m}^{2}$ ), Brachidontes adamsianus (Dunker, 1857) (13.56 organisms $/ \mathrm{m}^{2}$ ), Isognomon janus Carpenter, 1857 (1.84 organisms $/ \mathrm{m}^{2}$ ), and species POLYPLACOPHORA Class showing the highest density were Chiton articulatus Sowerby, 1832 (2.38 organisms $/ \mathrm{m}^{2}$ ) and Ischnochiton muscarius Reeve, 1847 (2.24 organisms $\left./ \mathrm{m}^{2}\right)$ (Figure 1).

The species with the widest distribution (Figure 1) were: L. mesoleuca, L. mitella, L. discors, F. gemmata, H. hansi, S. palmata, B. adamsianus and C. articulatus and represent $11.76 \%$. With regular distribution was recorded at $29.41 \%$ and irregular distribution was found in $58.82 \%$ of the species.

In GASTROPODA Class Crucibulum monticulus had the greatest size with $59.20 \mathrm{~mm}$ (minimum $=21.84 \mathrm{~mm}$, mean $=35.48 \mathrm{~mm}$ and standard deviation $=10.08)$. In GASTROPODA Class Crucibulum monticulus had the greatest size, and Nodilittorina modesta the smallest size, with $1.13 \mathrm{~mm}$ (maximum $=13.72 \mathrm{~mm}$, mean $=4.45$ $\mathrm{mm}$ and standard deviation $=1.74)$. In BIVALVIA Class Choromytilus palliopunctatus showed the greatest size, $55.99 \mathrm{~mm}$ (minimum $=4.90 \mathrm{~mm}$, mean $=17.19 \mathrm{~mm}$ and standard deviation $=7.70 \mathrm{~mm}$ ) and B. adamsianus the smallest size and was $2.16 \mathrm{~mm}$ (maximum $=13.81 \mathrm{~mm}$, mean $=5.87 \mathrm{~mm}$ and standard deviation $=1.26 \mathrm{~mm}$ ), (Figure 1).

In POLYPLACOPHORA Class, Chiton articulatus showed the greatest size and was $57.69 \mathrm{~mm}$ (minimum = $5.71 \mathrm{~mm}$, mean $=27.56 \mathrm{~mm}$ and standard deviation $=13.09 \mathrm{~mm}$ ) and showed the smallest size Lepidochitona $\mathrm{sp} 1$ and was $3.19 \mathrm{~mm}$ (maximum $=3.19 \mathrm{~mm}$, mean $=3.19 \mathrm{~mm}$ ).

The value of diversity index (H') calculated for the study area was $\mathrm{H}^{\prime}=4.29$ bits/ind and value Pielou index (J') was J' $=0.72$. By study site: Carrizalillo $\mathrm{H}^{\prime}=3.70$ bits/ind. and J'=0.0.68; Coral $\mathrm{H}^{\prime}=3.57 \mathrm{bits} / \mathrm{ind}$. and J'= 0.68 ; Punta Cometa H' $=2.68$ bits/ind. and J' $=0.62$. 


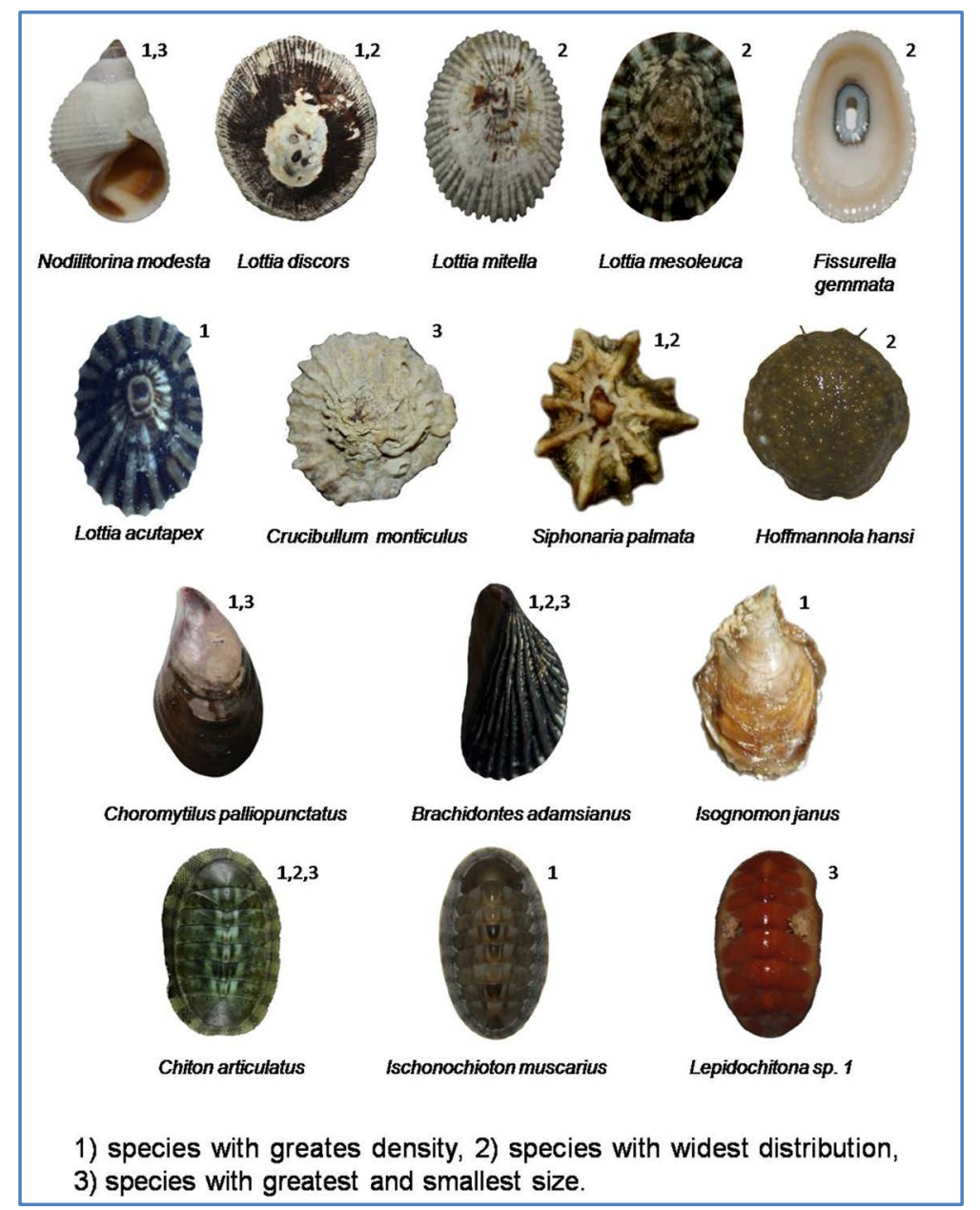

Figure 1. Mollusks of Oaxaca, with greatest density, widest distribution, greatest size and smallest size.

\section{Discussion}

In research conducted in one sampling site in the rocky intertidal zone of Oaxaca [7] [11] [20], they found fewer species which is reported in this research.

The greater number of species recorded in this study is attributed to sampling that was conducted at three sites that vary in type of substrate, stability and wave exposure, so the composition of the microhabitat is considerably varied and thus, a greater number of species is supported.

Reference [9] investigated the marine mollusks in the state of Oaxaca. Sampling was carried out by at sites with rocky and sandy substrates, located in the intertidal and subtidal zone, including a greater number of habitats, they found more species than is reported in this research.

In composition classes, all research was conducted at the respective sites in the rocky intertidal zone in the State of Oaxaca agree that the GASTROPODA Class has the highest species richness, a result that was also reported in the present investigation.

The BIVALVIA Class has been reported with higher species richness after GASTROPODA Class [7] [9] [11]. This research does not match this result, because after the GASTROPODA Class, found the highest species richness POLYPLACOPHORA Class, this result is equal to that reported for Acapulco [17] [22] [24], who sampled only in the rocky intertidal zone of Acapulco.

In the GASTROPODA Class, the families best represented in species richness were FISSURELLIDAE and MURICIDAE, [17] also reported these families as being among the greatest in species richness. Other research reports to the MURICIDAE Family as the best represented in species richness [7] [11] [16] [24]. 
In the BIVALVIA Class, MYTILIDAE and CHAMIDAE Families were better represented in species richness, as was reported for Acapulco by Galeana-Rebolledo et al. (2012). The CHAMIDAE Family was also reported by [17] as being the best represented in species richness.

In POLYPLACOPHORA Class families who turned out to be better represented in species richness were ISCHNOCHITONIDAE and CHITONIDAE, as was reported for Acapulco by [22]. The ISCHNOCHITONIDAE Family was also reported by [17] as the best represented in species richness.

The Families with higher abundance in the GASTROPODA Class were LOTTIDAE and SIPHONARIDAE, in BIVALVIA Class was the MYTILIDAE Family and POLYPLACOPHORA Class had the highest abundance CHITONIDAE Family. For the GASTROPODA Class, this research does not agree with what has been reported in research conducted on other sites in the Mexican Pacific Transitional, as occurs with [24], who found a COLUMBELLIDAE and TROQUIDAE as most abundant. In the BIVALVIA Class, MYTILIDAE Family also was reported by [11] and [20] as the most abundant, which differs from that reported for Acapulco by [22] [24], who found the CHAMIDAE Family to be the most abundant. In the POLYPLACOPHORA Class CHITONIDAE Family was also reported to be the best represented in abundance by [18] [22] [24].

The density values estimated for the study area are high. Other studies have also reported high densities in the region such as [15] [20] [17] [24]. In this research, the species with the highest density values for GASTROPODA, BIVALVIA and POLYPLACOPHORA Classes do not coincide with those reported in other research carried out in the Mexican Pacific Transitional.

Reference [21] reported for the state of Guerrero that $48 \%$ of mollusks species in the rocky intertidal zone of Guerrero had a wide distribution and $22.6 \%$ of the species showed irregular distribution. In the sites analyzed in this investigation, the number of species with wide distribution is considerably lower than that reported in Guerrero and the percentage of species with irregular distribution is significantly higher.

The GASTROPODA Class has the largest number of species with irregular distribution.

Regarding the size of the species, is coincides with reports from [17] [22]-[24], in which the largest Class size in GASTROPODA recorded in the genera Crucibullum, Lottia and Leucozonia; In BIVALVIA Class size is presented in most of the genera Choromytilus and Chama. The largest size in POLYPLACOPHORA Class, occurred in Chiton articulatus.

The results of this investigation indicate that mollusk species associated with the rocky intertidal zone, the maximum size rarely exceeds seventy millimeters in length. The same was reported for other sites that are located in the Mexican Pacific Transitional.

In the Mexican Transitional Pacific for mollusks associated with the rocky intertidal zone, have had high values reported for the diversity index of Shannon-Weaver [20] [22] [24]. For mollusks associated with the rocky intertidal zone in the Transitional Mexican Pacific, there are reports of high values for the Shannon-Weaver index.

The value of diversity index found by this research is high and corresponds to that expected in the rocky sites where this research was conducted.

With regard to uniformity for Transitional Mexican Pacific reports values were found around J' $>0.60$ [10] [17] [22] [24]. The values of J' reported in this study are similar to what has been reported in the above mentioned reports.

\section{Conclusions}

Species richness found in the study sites corresponds to that expected for rocky intertidal zones located in the Mexican Pacific Transitional. The GASTROPODA Class provides a greater number of species followed by the POLYPLACOPHORA Class.

Families considered as representative in species richness on the rocky intertidal zone of the study sites were FISSURELLIDAE and MURICIDAE (GASTROPODA), CHAMIDAE and MYTILIDAE (BIVALVIA) and CHITONIDAE (POLYPLACOPHORA).

Families considered as representative in abundance on rocky intertidal zones of the study sites were TROCHIDAE and COLUMBELLIDAE (GASTROPODA), MYTILIDAE (BIVALVIA) and CHITONIDAE (POLYPLACOPHORA).

The density found is high and corresponds to that expected in sites that are located in the Mexican Pacific transitional. 
Species considered representative by high density values recorded in the study area were, C. pallopuntatus, B. semilaevis and L. discors.

The mollusks community in the rocky intertidal study sites is characterized by small size, because they rarely exceed seventy millimeters. Among the species with larger size are Cruibullum monticulus; Ch. palliopunctatus and C. articulatus.

The values of H' and J' indicate that the mollusk community in the study area has a high diversity and high uniformity, corresponding to mature and stable communities in a tropical region.

\section{References}

[1] Wilkinson, T., Wiken, E., Bezaury Creel, J., Hourigan, T., Agardy, T., Herrmann, H., Janishevski, L., Madden, C., Morgan, L. and Padilla, M. (2009) Ecorregiones marinas de América del Norte. Comisión para la Cooperación Ambiental, Montreal.

[2] Arriaga, C.L., Vásquez, E., González, J., Jiménez, R., Muñoz, E. and Aguilar, B. (1998) Regiones Prioritarias Marinas de México: Comisión Nacional para el Conocimiento y uso de Biodiversidad, México, 198 p.

[3] Salcedo, M.S., Green, G., Gamboa, C.A. and Gómez, P. (1988) Inventario de macroalgas y macroinvertebrados bénticos, presentes en áreas rocosas de la región de Zihuatanejo, Guerrero, México. Anales del Instituto de Ciencias el Mar y Limnología. Universidad Nacional Autónoma de México, 15, 73-96.

[4] Reguero, M. and García-Cubas, A. (1989) Moluscos de la Plataforma Continental de Nayarit: Sistemática y Ecología (cuatro campañas oceanográficas). Anales del Instituto de Ciencias del Mar y Limnología. Universidad Nacional Autónoma de México, 16, 33-58.

[5] Holguín, O.E. and González, A.C. (1989) Moluscos de la franja costera del Estado de Oaxaca, México. Atlas No. 7 CICIMAR, Instituto Politécnico Nacional, Dirección de Bibliotecas y Publicaciones.

[6] Holguín, Q.O.E. and González, P.A.C. (1994) Moluscos de la franja costera de Michoacán, Colima y Jalisco, México. Instituto Politécnico Nacional, Dirección de Bibliotecas y Publicaciones, 133 p.

[7] De León-Herrera, M.G. (2000) Listado taxonómico de las especies de moluscos en la zona central del litoral oaxaqueño. Ciencia y Mar. Universidad del Mar, Oaxaca, México, 4, 49-51.

[8] Villaroel, M.M., Magaña, M.A., Gómez, C.B., Del Río, Z.O. and Sanchez, S.J. (2000) Diversidad de moluscos en el litoral rocoso de Michoacán, México. Revista de divulgación de investigacióncientífica. Mexicoa, 2, 54-63.

[9] Ramírez-González, A. and Barrientos-Luján, N.A. (2007) Moluscos de la zona intermareal de Cacaluta, bahías de Huatulco, Oaxaca, México. In: Ríos-Jara, E., Esqueda-González, M.C. and Galcván-Villa, C.M., Eds., Estudios sobre la Malocología y Conquiliología en México, Universidad de Guadalajara, México, 92-296.

[10] Román, C.R., Cruz, A.F.M. and Ibáñez A.A.L. (1991) Observaciones ecológicas de los moluscos de la zona intermareal de la bahía de Chamela, Jalisco, México. Anales del Instituto de Biología. Universidad Nacional Autónoma de México, 62, 17-32.

[11] Castillo-Rodríguez, Z.G. and Amezcua-Linares, F. (1992) Biología y aprovechamiento del caracol morado Plicopurpura pansa (Gould 1853) (Gastropoda:Neogastropoda) en la costa de Oaxaca, México. Anales del Instituto de Ciencias del Mar y Limnología. Universidad Nacional Autónoma de México, 19, 223-234.

[12] Esqueda, M.C., Riíos-Jara, E., Michel-Morfín, J.E. and Landa-Jaime, V. (2000) La distribución vertical y abundancia de gastrópodos y bivalvos de las playas rocosas de CuastecomateBay, Jalisco, México. Revista De Biologia Tropical, 48, 765-775.

[13] Valdés-González, A., Flores-Rodríguez, P., Flores-Garza, R. and García-Ibáñez, S. (2004) Molluscan Communities of Rocky Intertidal Zone at Two Sites with Different Wave Action on Isla la Roqueta, Acapulco, Guerrero, México. Journal of Shellfish Research, 23, 875-880.

[14] Hermosillo-González, A. (2006) Ecología de los Opistobranquios (Mollusca) de Bahía de Banderas, Jalisco-Nayarit, México. Tesis doctoral, Universidad de Guadalajara, Zapopan.

[15] Flores-Garza, R., Flores-Rodríguez, P., García-Ibáñez, S. and Valdés-González, A. (2007) Demografía del Caracol Plicopurpura pansa (Neotaenioglossa: Muricidae) y constitución de la comunidad malacológica asociada en Guerrero, México. Revista de Biológica Tropical, 55, 867-878.

[16] Flores-Garza, R., Galeana-Rebolledo, L., García-Ibáñez, S., Flores-Rodríguez, P. and Torreblanca-Ramírez, C. (2010) Diversidad y estructura de la comunidad de Polyplacophora en el mesolitoral rocoso, Acapulco, Guerrero, México. In: Rangel, L.J., Gamboa, J., Arriaga, S.L. and Contreras, W.M., Eds., Perspectiva en malacología mexicana, Universidad Juárez Autónoma de Tabasco, Villahermosa, 141-152.

[17] Flores-Garza, R., Torreblanca-Ramírez, C., Flores-Rodríguez, P., García-Ibáñez, S., Galeana-Rebolledo, L., ValdésGonzález, A. and Rojas-Herrera, A. (2011) Mollusca Community from a Rocky Intertidal Zone in Acapulco, México. 
Biodiversity, 12, 144-153. http://dx.doi.org/10.1080/14888386.2011.625520

[18] Flores-Garza, R., Galeana-Rebolledo, L., Reyes-Gómez, A., García-Ibáñez, S., Torreblanca-Ramírez, C., Flores-Rodríguez, P. and Valdés-González, A. (2012) Polyplacophora Species Richness, Composition and Distribution of Its Community Associated with the Intertidal Rocky Substrate in the Marine Priority Region No. 32 in Guerrero, Mexico. Open Journal of Ecology, 2, 192-201. http://dx.doi.org/10.4236/oje.2012.24023

[19] Flores-Rodríguez, P., Flores-Garza, R., García-Ibáñez, S. and Valdés-González, A. (2007) Variación en la diversidad malacológica del mesolitoral rocoso en Playa Troncones, La Unión, Guerrero, México. Revista Mexicana de Biodiversidad, 78, 33S-40S.

[20] Flores-Rodríguez, P., Barba-Marino, F., Flores-Garza, R., García-Ibáñez, S. and Arana-Salvador, D.G. (2010) Análisis de la comunidad de moluscos del mesolitoral rocoso en playa Corralero, Oaxaca, México. In: Rangel, L.J., Gamboa, J., Arriaga, S.L. and Contreras, W.M., Eds., Perspectiva en Malacología Mexicana, Universidad Juárez Autónoma de Tabasco, Villahermosa, Tabasco, México, 125-138.

[21] Flores-Rodríguez, P., Flores-Garza, R., García-Ibáñez, S., Valdés-González, A., Violante-González, J., Enedina, S.C., Galeana-Rebolledo, L. and Torreblanca-Ramírez, C. (2012) Mollusk Species Richness on the Rocky Shores of the State of Guerrero, Mexico, as Affected by Rains and Their Geographical Distribution. Natural Resources, 3, 248-260. http://www.SciRP.org/journal/nr http://dx.doi.org/10.4236/nr.2012.34032

[22] Galeana-Rebolledo, L., Flores-Garza, R., Torreblanca-Ramírez, C., García-Ibáñez, S., Flores-Rodríguez, P. and LópezRojas, V.I. (2012) Biocenosis de Bivalvia y Polyplacophora del intermareal rocoso en playa Tlacopanocha, Acapulco, Guerrero, México. Latin American Journal of Aquatic Research, 40, 943-954. http://dx.doi.org/10.3856/vol40-issue4-fulltext-11

[23] Galeana-Rebolledo, L., Flores-Garza, R., Reyes-Gómez, A., García-Ibáñez, S., Flores-Rodríguez, P., Torreblanca-Ramírez, C. and Valdés-González, A. (2014) Species Richness and Community Structure of Class Polyplacophora at the Intertidal Rocky Shore on the Marine Priority Region No. 33, Mexico. 4, 43-52.

[24] Torreblanca-Ramírez, C., Flores-Garza, R. Flores-Rodríguez, P., García-Ibáñez, S. and Galeana-Rebolledo, L. (2012) Riqueza, composición y diversidad de la comunidad asociada al sustrato rocoso intermareal de playa Parque de la Reina, Acapulco, México. Revista de Biología y Oceanografía, 47, 283-294. http://dx.doi.org/10.4067/S0718-19572012000200010

[25] Baqueiro, E. and Stuardo, J. (1977) Observaciones sobrela biología, ecología y explotación de Megapitariaaurantiaca (Sowerby, 1831), M. squalida (Sowerby, 1835) y Dosinia ponderosa (Gray, 1838) (Bivalvia: Veneridae) de la bahía de Zihuatanejo e isla Ixtapa, Guerrero, México. Anales del Centro de Ciencias del Mar y Limnología, Universidad Nacional Autónoma de México, 161-208.

[26] Flores-Garza, R., García-Ibáñez, S., Flores-Rodríguez, P., Torreblanca-Ramírez, C., Galeana-Rebolledo, L., Valdés-González, A. and Suástegui-Zárate, A. (2012) Commercially Important Marine Mollusksfor Human Consumption in Acapulco, México. Natural Resources, 3, 11-17. http://www.SciRP.org/journal/nr http://dx.doi.org/10.4236/nr.2012.31003

[27] Zamorano, P., Barrientos-Lujan, N.A. and Leyte-Morales, G.E. (2006) Cambios en la diversidad y abundancia de especies dominantes de moluscos en la zona coralina de La Entrega, Oaxaca. CICIMAR Oceanides, 21, 101-111.

[28] Reyes-Gómez, A., Barrientos-Lujan, N., Medina-Bautista, J. and Ramírez-Luna, S. (2010) Chitons from the Coralline Area of Oaxaca, Mexico (Polyplacophora). Bolletino Malacologico, 46, 111-125.

[29] Landa-Jaime, V. and Arciniega-Flores, J. (1998) Macromoluscos bentónicos de fondos blandos de la plataforma continental de Jalisco y Colima, México. Ciencias Marinas, 24, 155-167.

[30] Ríos-Jara, E., Pérez-Peña, M., Beas-Luna, R., López-Uriarte, E. and Juárez-Carrillo, E. (2001) Gastropods and Bivalves of Commercial Interest from the Continental Shelf of Jalisco and Colima, Mexico. Revista De Biologia Tropical, 49, 785-789.

[31] Villalpando Canchola, E. (1986) Diversidad y zonación de moluscos de facie rocosa isla Roqueta, Acapulco Gro. Tesis profesional inédita, Facultad de Ciencias, Universidad Nacional Autónoma de México, México D.F.

[32] Barba-Marino, F., Flores-Rodríguez, P., Flores-Garza, R., García-Ibáñez, S. and Arana-Salvador, D.G. (2010) Biodiversidad y zonificación de la comunidad de moluscos, que habita el sustrato rocoso en dos sitios con distinta acción del oleaje, en la Isla "La Roqueta” Acapulco, Guerrero, México. In: Rangel, L.J., Gamboa, J., Arriaga, S.L. and Contreras, W.M., Eds., Perspectiva en Malacología Mexicana, Universidad Juárez Autónoma de Tabasco, Villahermosa, 125138.

[33] García, E. (1973) Modificaciones al sistema de clasificación climática de Köppen para adaptarlo a las condiciones particulares de la República Mexicana.

[34] Carranza-Edwards, A., Gutiérrez-Estrada, M. and Rodríguez-Torres, R. (1975) Unidades morfo-tectónicas continen- 
tales de las costas mexicanas. Anales del Instituto de Ciencias del Mar y Limnología, 2, 81-88.

[35] Carranza-Edwards, A., Rosales-Hoz, L. and Lozano-Santa Cruz, R. (1988) Estudio sedimentológico de playas del estado de Oaxaca, México. Anales Del Instituto de Ciencias Del Mar y Limnolog, 15, 23-38.

[36] Hubbs, C.L. and Roden, G.I. (1964) Oceanography and Marine Life along the Pacific Coast of Middle America. Handbook of Middle American Indians. I. The University of Texas Press, Austin.

[37] Mottana, A., Crespi, R. and Liborio, G. (1980) Guía de minerales y rocas. segunda edición, Grijalbo, Barcelona.

[38] SGM (2002) Carta Geológica-Minera Puerto Escondido D14-3, Oaxaca, escala 1:250,000. Servicio Geológico Mexicano, Pachuca.

[39] INEGI (2013) Carta geológica digital, escala 1:1000000. Instituto Nacional de Estadística, Geografía e Informática. Aguascalientes. http://www.inegi.org.mx/geo/contenidos/recnat/geologia/InfoEscala.aspx

[40] Scheaffer, R.L., Mendenhall, W. and Ott, L. (1987) Elementos de muestreo, tercera edición, Iberoamericano.

[41] Keen, A.M. (1971) Sea Shells of Tropical West America. Stanford University Press, California.

[42] Kaas, P. and Van Belle, R.A. (1994) Monograph of Living Chitons (Mollusca: Polyplacophora).Vol. 5: Suborder Ischnochitonina: Ischnochitonidae: Ischnochitoninae (Concluded); Callistoplacinae; Mopaliidae. E.J. Brill/W. Backhuys, Leiden.

[43] Reyes-Gómez, A. and Salcedo-Vargas, M.A. (2002) The Recent Mexican Chiton (Mollusca: Polyplacophora) Species. The Festivus, 34, 17-27.

[44] Ortiz-Arellano, M.A. and Flores-Campaña, L.M. (2008) Catálogo descriptivo e ilustrado de los moluscos de la zona intermareal de las Islas de Navachiste, Sinaloa, México. Universidad Autónoma de Sinaloa-Consejo Nacional de Ciencias y Tecnología, Mazatlán.

[45] Skoglund, C. (2001) Panamic Province Molluscan Literature Additions y Changes from 1971 through 2000 I Bivalvia y II Polyplacophora. The Festivus, 32, 1-119.

[46] Skoglund, C. (2002) Panamic Province Molluscan Literature Additions and Changes from 1971 through 2001, III Gastropoda. The Festivus, 33, 1-286.

[47] Hermosillo, A., Behrens, D.W. and Ríos, J.E. (2006) Opistobranquios de México: Guía de babosas marinas del Pacífico, Golfo de California y las islas oceánicas. Conabio, México.

[48] Sirenko, B. (2006) New Outlook on the System of Chitons (Mollusca: Polyplacophora). Venus, 65, 27-49.

[49] Magurran, A.E. (1988) Ecological Diversity and Its Measurement. Princeton University Press, Princeton. 
Scientific Research Publishing (SCIRP) is one of the largest Open Access journal publishers. It is currently publishing more than 200 open access, online, peer-reviewed journals covering a wide range of academic disciplines. SCIRP serves the worldwide academic communities and contributes to the progress and application of science with its publication.

Other selected journals from SCIRP are listed as below. Submit your manuscript to us via either submit@scirp.org or Online Submission Portal.
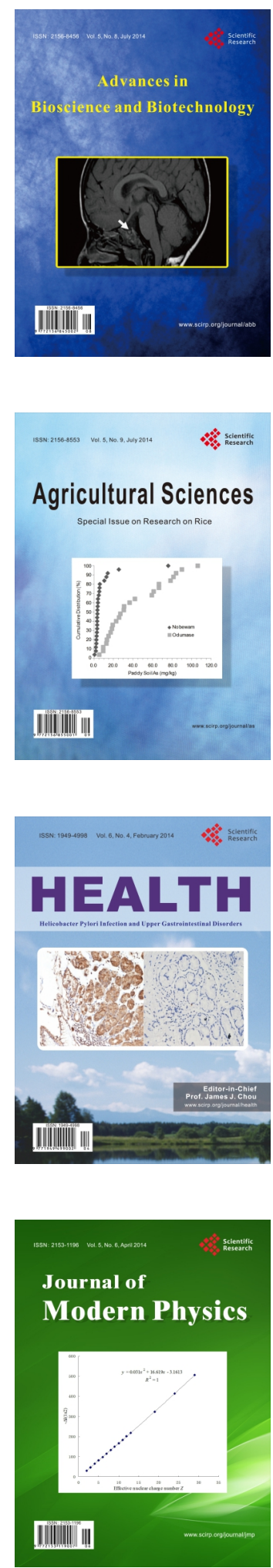
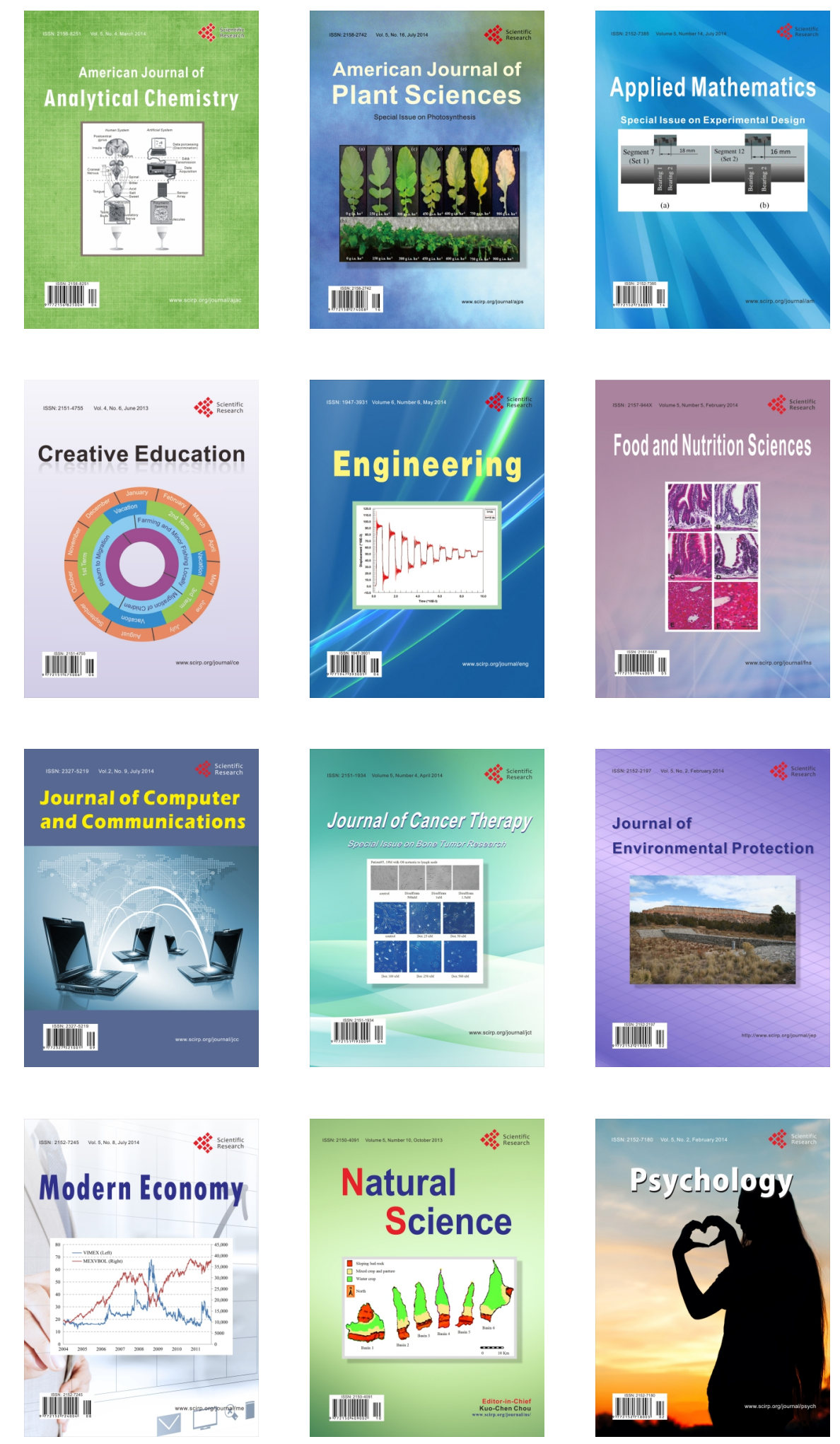